Aletria, Belo Horizonte, v. 29, n. 4, p. 65-82, 2019

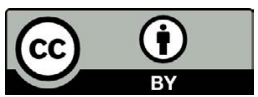

\title{
$O$ anjo e a besta: a antropologia pascaliana no laboratório de Machado de Assis
}

\section{The Angel and the Beast: Pascalian Anthropology at the Laboratory of Machado de Assis}

\author{
Alex Lara Martins \\ Instituto Federal do Norte de Minas Gerais (IFNMG), Almenara Minas Gerais / Brasil \\ alexlm@bol.com.br
}

Resumo: A ficção de Machado de Assis coloca em disputa a metáfora antropológica utilizada pelo filósofo Blaise Pascal para descrever a natureza ambígua do ser humano. Neste artigo, revela-se o processo que levou Machado a apropriar-se da antropologia pascaliana. O recorte deste processo incide sobre o conjunto de crônicas "Notas Semanais", escrito em 1878. Machado antecipa alguns pressupostos do que conhecemos por literatura fantástica, dando vida a seres inertes, compilando uma espécie de bestiário, descrevendo espetáculos com animais fabulosos e monstruosidades humanas. O leitor e a plateia, que se divertem e contemplam o espetáculo, se rebaixam e se transformam, igualmente, em bestas. Saiba-se que a falência do projeto romanesco de caracteres e a recusa das doutrinas literárias realistas são alguns dos motivos que forçaram Machado a reinventar a forma narrativa. Do mesmo modo, os pressupostos da antropologia pascaliana são redirecionados para uma investigação cética, e até grotesca, da realidade.

Palavras-chave: jansenismo; Machado de Assis; Blaise Pascal; bestialização; ceticismo.

Abstract: The fictional works of Machado de Assis challenge Blaise Pascal's anthropological metaphor. It is used to describe the ambiguous nature of the human being. In this article, we reveal the process that led Machado to take possession of the Pascalian anthropology. The focus is the set of chronicles "Notas Semanais", written in 1878. Machado anticipates some assumptions of what we know by fantastic literature, giving life to inert beings, compiling a kind of bestiary, describing spectacles with fabulous animals and human monstrosities. The reader and the audience, who amuse themselves and contemplate the spectacle, become equally beasts. It should be noted that 
the ruin of the Romanesque project and the rejection of the realistic literary doctrines are some of the reasons that forced Machado to reinvent the narrative form. In the same way, the assumptions of Pascalian anthropology are redirected to a skeptical, and even grotesque, inquiry of reality.

Keywords: jansenism; Machado de Assis; Blaise Pascal; bestialization; skepticism.

\section{Introdução}

O filósofo jansenista Blaise Pascal concebe o ser humano como se fosse um monstro, composto por duas naturezas opostas: "o homem não é anjo nem besta", ${ }^{1}$ mas encontra-se no meio destes contrários, e quanto mais se pretenda angelical, tanto mais o percebemos bestializado. Essa metáfora compreensiva permite ao jansenista dramatizar a miséria humana sem Deus, em acordo com a doutrina cristã. Essa versão dramatizada do que seja a natureza humana estendeu o pano de fundo teórico para o romance de caracteres francês. As estórias de Mme. de Lafayette (La Princesse de Clèves) e Abbé Prévost (Manon Lescaut) trataram de escrutinar a condição humana utilizando-se do léxico pascaliano: o divertimento, o tédio, a miséria e a grandeza, a necessidade da aposta cega em Deus, as contradições humanas, a queda e a redenção. ${ }^{2}$

No caso das Memórias Póstumas de Brás Cubas, de Machado de Assis, mesmo que seja correta a atribuição das influências inglesas, por exemplo, de Swift e Sterne, elas atingem mais o aspecto da organização narrativa, com seus avanços, retrocessos e atropelos, do que o pensamento ficcional ali expresso e as concepções de homem e de mundo. Assim, a reconstituição dos juízos de valor, da história das ideias e das mentalidades também pode fornecer pistas para os critérios estéticos da obra. Dito com outras palavras,

para reconstruir esse modo de olhar seria preciso entender os encontros e os desencontros do moralismo clássico e jansenista (severo até o limite do pessimismo) e a concepção liberal-capitalista da natureza humana, que

\footnotetext{
${ }^{1}$ PASCAL. Pensamentos, p. 279 (La 678; Br 358). Os fragmentos dos Pensamentos de Pascal estão referidos, respectivamente, de acordo com a numeração das edições de Lafuma (La) e Brunschvicg (Br).

${ }^{2}$ MATHIEU. Mme de Lafayette et la condition humaine: Lecture pascalienne de $L a$ Princesse de Clèves, p. 61.
} 
tentou, pela voz dos precursores da Economia Política, conciliar o cinismo do interesse individual com a hipocrisia da burguesia que celebrava como progresso do gênero humano a prosperidade de sua classe. ${ }^{3}$

Ao puxar a linha desta trama, pode-se conjecturar que Machado - e parte dos intelectuais de sua geração - tivesse seguido a recomendação do filósofo eclético Victor Cousin para o retorno aos clássicos, especialmente a Pascal e a sua ideia universalista, mas conflitante, de homem. ${ }^{4}$ Este descarrilamento de rota era parte do plano dos intelectuais da Revue des Deux Mondes, que se opunham às estéticas do homem terra a terra realista e do homem fantasiado do romantismo. A superação eclética pressupunha o retorno à antropologia clássica de Pascal, da qual ele mesmo era o modelo: o místico e o cientista resumiam o conflito eterno entre a vontade e o intelecto, a besta e o anjo.

Este artigo se divide em duas partes. A primeira revela o processo que levou Machado a apropriar-se da antropologia pascaliana, que já circulava como fato social adaptado ao caso brasileiro. O recorte deste processo formativo incide sobre o conjunto de crônicas "Notas Semanais", escritas para o jornal $O$ Cruzeiro, nas quais se busca um ponto de vista adequado para expressar a dicotomia humana. A segunda parte aproxima o cronista de alguns pressupostos do que conhecemos como literatura fantástica, dando vida a seres inertes, compilando uma espécie de bestiário, descrevendo espetáculos com animais fabulosos e monstruosidades humanas. O leitor e a plateia, que se divertem e contemplam o espetáculo, se rebaixam e se transformam, igualmente, em bestas. Saiba-se que a falência do projeto romanesco de caracteres e a recusa das doutrinas literárias realistas são alguns dos motivos que forçaram Machado a reinventar a sua forma narrativa. Do mesmo modo, os pressupostos da antropologia pascaliana - como a intenção apologética e exortativa - são redirecionados para uma investigação cética e até grotesca da realidade.

\section{A perspectiva cética do cronista Machado de Assis}

No conjunto de crônicas "Notas Semanais", de 1878, Machado de Assis concebe o ser humano, ao mesmo tempo, como besta, que busca

${ }^{3}$ BOSI. O enigma do olhar, p. 168.

${ }^{4}$ COUSIN. Des Pensées de Pascal. 
irrefletidamente nutrir a sua "porção sensual" e como anjo, que tem a capacidade intelectual para compreender a sua miséria. Na realização dessa inspeção antropológica, o cronista reflete sobre a sua própria atividade literária, alcançando "certa altura" de olhar, que lhe permitirá apreender e compor a dualidade entre a escrita e a vida. Nisso, as crônicas dessa série funcionam como um laboratório para que Machado desenvolva a forma narrativa a ser empregada dois anos depois, nas Memórias póstumas de Brás Cubas, de cujo ponto de vista o narrador tem a pretensão de interpretar fidedignamente o mundo dos vivos.

John Gledson e Lúcia Granja afirmam que é o leitmotiv de toda a série, "poeira nos olhos é a regra máxima de um tempo que vive menos da realidade que da opinião". ${ }^{5}$ Machado refletia sobre o uso intencional do embuste e da velhacaria para a sobrevivência do indivíduo no meio social. Aqui, mais importante do que uma teoria cética sobre as opiniões humanas é a identificação do cronista com a figura do misantropo, o único capaz de conhecer a verdade de que as relações humanas se fundamentam no engano mútuo, em "amável formalidade", se quisermos antecipar a metáfora compreensiva das Memórias póstumas. Para dizer isso, sem embolsar a contradição dos termos, ele se esforça para construir uma perspectiva adequada, que imite a vida, mas mantenha dela certa distância: "Verdade é que, assim como a vida é entremeada de reflexões e pilhérias, também o folhetim pode, uma vez ou outra, sacudir a sua tosse parlamentar e deitar ao mundo uma ou duas observações de calibre sessenta". ${ }^{6}$

Isso significa duas coisas: primeiro, que é possível construir um forte de fidedignidade que cerque os juízos emitidos da vala comum opiniática; fortificação que permita ao emissor superar até as críticas de um relativista moral. Ou seja, os critérios científicos do cronista consistem em: (1) reinterpretar os fatos importantes da semana; (2) oferecer hipóteses mais razoáveis do que as explicações convencionais; (3) combinar características e questões nacionais com definições generalizantes de homem e de sociedade. Em conjunto, essas características resultam em uma combinação sui generis de um ironista dado a criar hipóteses metafísicas sobre a psicologia humana e sobre a essência do mundo. O ironista se distingue pela autorreflexão e pela emissão de aporias e dilemas morais, cuja tradição literária remonta à

\footnotetext{
${ }^{5}$ ASSIS apud GLEDSON; GRANJA. Notas Semanais, p. 47.

${ }^{6}$ ASSIS. Obras completas em quatro volumes, p. 432.
} 
ironia e à maiêutica socráticas, com perguntas e respostas insatisfatórias. O metafísico se distingue pela busca de princípios e conceitos capazes de descrever a substância da vida, ora partindo-se de um método dedutivo, em que os princípios são concebidos a priori, ora analisando-se casos individuais e contextualizados.

Veja-se a quinta crônica da série, em que se tira a conclusão de que "o homem é um animal eternamente brigão", 7 quando se estava a falar do novíssimo costume carioca de apostar em corridas e saltos. A imagem que o ironista metafísico idealiza para si, de alguém capaz de alhear-se às perturbações, é reinterpretada na autoimagem que o cronista possui, de alguém capaz de

fumar quietamente o cachimbo do seu fatalismo. $O$ cronista não tem cargo-d'almas, não evangeliza, não adverte, não endireita os tortos do mundo; é um mero espectador, as mais das vezes pacato, cuja bonomia tem o passo tardo dos senhores do harém. Debruça-se, cada domingo, à janela deste palacete, e contempla as águas de Bósforo, a ver os caíques que se cruzam, a acompanhar de longe a labutação dos outros. $^{8}$

Em segundo lugar, a passagem anterior nos faz pensar que o andamento da vida, misto grotesco de "reflexões e pilhérias", possa ser copiado pelo gênero literário, misturando o cômico e o sério ou, para antecipar novamente as Memórias póstumas, a galhofa e a melancolia. O mesmo pode ser pensado, no início da sexta crônica, onde se diz que "o folhetim requer um ar brincão e galhofeiro, ainda tratando de coisas sérias". ${ }^{9} \mathrm{O}$ argumento de Machado segue mais ou menos a lógica da prova pela doutrina, de Pascal:

As grandezas e as misérias do homem são tão visíveis que é absolutamente necessário que a verdadeira religião nos ensine tanto que existe algum grande princípio de grandeza

\footnotetext{
${ }^{7}$ ASSIS, Obras completas em quatro volumes, p. 395.

${ }^{8}$ ASSIS. Obras completas em quatro volumes, p. 397. Machado refere-se aqui às consequências do tratado de Berlim para o Império Otomano (Turquia), em que se chocavam os interesses políticos de países ocidentais (Grã-Bretanha, Áustria-Hungria) e orientais (Rússia), representados pelo estreito de Bósforo, que corta a península turca. ${ }^{9}$ ASSIS. Obras completas em quatro volumes, p. 397.
} 
no homem como também que há ele um grande princípio de miséria. É também necessário que ela nos explique a razão dessas espantosas contrariedades [...]. Não acho que devais submeter vosso crédito a mim sem razão, nem pretendo submeter-vos de modo tirânico. Não pretendo tampouco mostrar-vos as razões de todas as coisas. E para conciliar essas contrariedades tenho a intenção de fazer-vos ver claramente, mediante provas convincentes, marcas divinas em mim, que vos convençam do que eu sou e conseguir para mim autoridade mediante maravilhas e provas que não possuais recusar e que em seguida creiais nas coisas que vos ensino quando nelas não encontrardes outro motivo de recusa senão que não podeis por vós mesmos conhecer se elas são ou não. ${ }^{10}$

A semelhança dos argumentos está na intenção de fazer crer, mediante uma sequência narrativa que explique a vida humana, isto é, que esteja no mesmo compasso da realidade. Além disso, a própria forma de emissão do argumento, para se tornar efetivamente persuasivo, deve ser compatível com o conteúdo da explicação. De acordo com Pascal, essas condições são cumpridas pela doutrina cristã, cuja sequência narrativa, da queda à redenção, exprime adequadamente - em comparação tanto com as demais religiões quanto com as doutrinas filosóficas - a natureza humana, não totalmente racional nem sobrenatural, nem divina nem bestializada. Conforme o cenário pascaliano, contudo, encontram-se fechados os acessos ao conhecimento da glória com Deus e ao desespero da miséria sem Deus. Para o cronista, a forma deste argumento ainda parece válida, desde que se substitua a instância religiosa pela ficcional.

O cronista pretende que a sua lógica de explicação de mundo esteja mais adequada que a de seus concorrentes, quais sejam, a do cientista e a do divulgador de boatos. É preciso reconhecer as artimanhas do silogismo machadiano. O cronista constrói pequenas teorias, com suposições e premissas manifestamente falsas, além de raciocínios condicionais, para combater e superar as notícias, pretensamente verdadeiras, contadas por outros jornalistas. Machado não está apenas relembrando os tempos da Petalógica, em que se competia pela maior mentira, ${ }^{11}$ senão que estivesse a desconfiar da relação entre as opiniões midiáticas e a realidade. Este

${ }^{10}$ PASCAL. Pensamentos, p. 65-66 (La 149; Br 430).

${ }^{11}$ MASSA. A juventude de Machado de Assis, p. 85. 
método heurístico é utilizado em mais da metade das crônicas, surgindo logo na primeira, por ocasião do incêndio em um prédio municipal, cuja explicação corrente era a de combustão espontânea, "a mais verossímil de todas". Então, o cronista dá início a uma série de condicionais. Se for "combustão espontânea", isso quer dizer que a edificação é um ser com vontade própria. A conclusão, portanto, é que

[o] mau costume que têm todos os paços municipais de dormirem com luz, e lerem até alta madrugada. O de Macacu parece que até fumava na cama. Imprudência que se não combina com a madureza própria de um paço municipal. ${ }^{12}$

A pilhéria é seguida pela consideração grave de que a história do município se perdia com a destruição dos documentos. Nada mau se pensarmos que a história - a ciência histórica - loureira e disposta a qualquer narrativa, é dispensável: "para isso a maior fortuna seria aplicar o niilismo aos documentos. Entreguemos os sábios vindouros ao simples recurso da conjectura; aplicação higiênica, algo fantástica, e sobretudo pacífica". ${ }^{13} \mathrm{Na}$ semana seguinte, o cronista retoma o "recurso da conjectura". A nova suposição era a de que o edifício ardeu devido a "oculto propósito" partidário. O cronista de Machado de Assis a desacredita, oferecendo outras condicionais: supôs o incêndio porque não encontraram o prédio no lugar de costume. Se bem que fosse másculo na aparência, o paço dissimulava ser uma "bela sexagenária" que passou a vida revezando entre os partidos que ali habitaram. Ela engravidou e, como a vila fosse a recatada de bons costumes, por medo de uma execração universal, ela fugiu para a rua do Ouvidor, local em que se descomplicavam a primeira e a segunda natureza, o instinto e o costume:

O incêndio era, pois, uma calúnia, um aleive, uma inverdade, se me é lícito usar este barbarismo. Era uma maneira de julgar pelas aparências; era mais alguma coisa. Se delato o erro da infeliz, é porque há fortes esperanças de o santificar pelo matrimônio. Assim, não prejudico a situação profundamente municipal do paço, e arredo de sobre a cabeça dos partidos a suspeita de terem traduzido

${ }^{12}$ ASSIS. Obras completas em quatro volumes, p. 378.

${ }^{13}$ ASSIS. Obras completas em quatro volumes, p. 378 
em macacuense as doutrinas da comuna. As fraquezas do coração, pode absorvê-las a igreja; a história é que não tem bênçãos para o erro político. Sabia-o Macacu; saiba-o o universo inteiro. ${ }^{14}$

Machado poderia estar manejando intuitivamente os recursos do conectivo lógico "se-então". Numa implicação material, sempre que o antecedente for verdadeiro, o consequente também o será, ou melhor, não é o caso de o antecedente ser verdadeiro e o consequente, falso. Se a combustão é espontânea, então o prédio possui vida própria, e se ele possui vida, então pode passear por aí. É claro que a sequência de transmissão de verdade está baseada na ambiguidade, em linguagem natural, do termo "espontânea", que pode significar involuntariamente, isto é, sem a intervenção humana, ou voluntariamente, isto é, que se manifesta por si mesmo. Mas o que pode espantar é que não temos informações suficientes para saber o valor de verdade do consequente numa situação em que o antecedente é falso ou apresenta premissas inconsistentes. E o que faz o cronista senão certificar a inconsistência das premissas? Assim, a segunda hipótese para o caso - a de um incêndio com propósitos partidários - transforma-se num apólogo burlesco de um edifício que é uma solteirona grávida. Apesar disso, não precisamos ir tão longe a ponto de defender que a intuição de Machado captura os pressupostos da lógica formal. ${ }^{15}$ Basta dizer que ele aprendeu com Pascal e outros filósofos a força argumentativa da hipótese e da modalidade alética, cujas operações podem se valer de premissas absurdas, ambíguas ou fantásticas para se concluir algo que não pode ser contestado racionalmente. Por exemplo, diz Pascal, para se conhecer a vaidade dos homens, basta conhecer as causas e os efeitos do amor: "o nariz de Cleópatra, se tivesse sido mais curto, toda a face da terra teria mudado". ${ }^{16}$ Ele faz notar que a vaidade

\footnotetext{
${ }^{14}$ ASSIS. Obras completas em quatro volumes, p. 381.

${ }^{15}$ A aproximação entre a ficção machadiana e a tradição dita analítica da filosofia não é uma inovação. Ver DIXON. A auto-referência e o paradoxo em Dom Casmurro. p. 3040; DIXON. Teoria da mente, Machado de Assis, e a escola realista, p. 84-93; PRATT. Toward a Speech Act Theory of Literary Discourse; MAIA NETO. Machado de Assis: skepticism and literature, p. 26-35; MARGUTTI PINTO. Richard Rorty and Machado de Assis: Two Different Ways of Coping with Ironism, p. 115-139.

${ }^{16}$ PASCAL. Pensamentos, p. 157 (La 413; Br 162). Na sequência, ver os fragmentos La 18,163 e 750.
} 
humana é tão frívola que um elemento insignificante, como o tamanho de um nariz ou de um capuz pode produzir um efeito de escala planetária. O inverso também é o caso, isto é, coisas de extrema importância, como saber se a própria sentença foi pronunciada ou se é viável conquistar um reino, são preteridas por divertimentos e situações insignificantes. Pascal joga com os termos metafísicos "impossível", "infinito"e "absurdo" para convencer de situações possíveis, finitas e reais.

O "efeito Cleópatra" está suposto na proposta de Brás Cubas a respeito do tamanho da barretina da Guarda Nacional. De demonstrações a citações históricas e a razões científicas, Brás realiza um discurso eloquente, em que emprega a forma "literária e filosófica" para convencer os deputados da grandeza daquela mudança ínfima. Também o cronista faz coro ao "efeito Cleópatra" ao tecer comentários sobre a dupla natureza humana, misto de feiura e beleza, ignorância e sabedoria:

Tão normal era a beleza humana, que Sócrates, ao passo que nos transmitiu as suas ideias, transmitiu-nos também o seu nariz, aquele nariz que tinha tanto de grego, como o de Cleópatra tinha de escandinavo: um nariz que, se hoje não incorre em nenhuma incapacidade eleitoral ou social, naquele tempo devia ser bem triste de admitir-se entre os olhos de um cidadão. Pois esse nariz veio até nós, - como um exemplo de exceção na regularidade nasal dos gregos. Feliz Hélade, onde os olhos encontravam na figura humana a simples, a adorável elegância da linha dórica, e a graça da ornamentação coríntia; onde quase que era preciso inventar o monstro. ${ }^{17}$

Sócrates e Cleópatra são os modelos clássicos, respectivamente, de virtude e de beleza. Porque fosse o mais sábio de todos, Sócrates nos transmitiu, além da sabedoria (em parte vinculada à ignorância), as condições do feio e do grosseiro representadas em seu nariz. Ele se tornava, assim, grego e antigrego, divino e animal. Daqui até as Memórias póstumas, a bestialização será um dos processos preferidos de Machado. O corpo humano será fustigado e barbarizado de diversos modos. Para ficarmos com os personagens do romance, o escravizado Prudêncio será agrilhoado feito uma "besta" pelo "brejeiro" Brás Cubas. O rosto de Marcela deteriorar-se-á da sífilis. Eugênia mancará. O Cotrim

${ }^{17}$ ASSIS. Obras completas em quatro volumes, p. 390. 
mandará escravos ao calabouço, fazendo correr o seu sangue. Quincas Borba sofrerá demência e o próprio Brás Cubas terá alucinações com animais e se misturará a eles enquanto sofrem mutações. Esta descrição paradoxal e monstruosa da natureza humana exige, para ser percebida e reconfigurada, um ponto de vista igualmente paradoxal e monstruoso, como se o próprio cronista tivesse que inspecionar a realidade por meio de conjecturas irrealizadas.

\title{
$O$ anjo e a besta: antropologia pascaliana instaurada
}

Para descrever o processo de maneira precisa, o narrador e o cronista recorrem à figura do oximoro ou paradoxismo, que consiste em formar conceitos por meio da combinação de palavras com sentidos opostos. O Brasinho foi o "menino diabo". Eugênia era bonita e coxa. E assim por diante. Lúcia Granja afirma que

\begin{abstract}
o horripilante, aqui recortado a partir do abuso do corpo humano e animal em relações que envolvem várias manifestações do poder, é incorporado à ficção machadiana como paródia da naturalização de certos discursos e práticas das sociedades em geral. Melhor dizendo, na ficção, a legitimação da violência pelos procedimentos da criação e, sobretudo, pelo relato quase desumanizado dos narradores, revela a matéria inverossímil do viver: da escravidão tardia, dos abusos cometidos pela ciência experimental em busca de explicações, ou, ainda, da "deturpação" do gosto estético. ${ }^{18}$
\end{abstract}

Deste modo, a pretensão do narrador em representar fidedignamente a realidade sofre uma espécie de torção, na medida em que o mundo da vida é recheado de paradoxos e contradições. Em relação ao cronista de 1878, a estratégia retórica possui a sutileza da lógica de construção de hipóteses ficcionais. Em vez do apego à realidade, que não raro se desfaz, ele a revisa tendo em vista discursos e acontecimentos de ordem cultural:

${ }^{18}$ GRANJA. Machado de Assis, esse escritor monstruoso (entre aberrações e espetáculos), p. 143. 
[O] aleijão é necessário à harmonia das coisas; o monstro é o complemento da beleza. Os antigos, que entendiam do riscado, casaram Vênus e Vulcano; e a lenda cristã reuniu a beleza física à fealdade moral, na pessoa do anjo réprobo. ${ }^{19}$

A complementaridade dos opostos é o principal argumento utilizado pelo cronista para explicar a natureza humana. O "homempeixe", cujo espetáculo era recheado por acrobacias debaixo d'água, possuía "uma e outra natureza", tal como o morcego, que é pássaro no ar e rato em terra. Este benefício da dualidade - a "virtude de ser duas coisas" - fora concedido ao indivíduo, que recebe o aplauso e a estima de outros iguais. O bestiário humano completa-se, nas crônicas, com a "ondina" (versão feminina do homem-peixe), o levantador de pesos, os lutadores e os corredores, que lutam e correm feito animais.

Como vimos, a amplitude de vistas, o "olhar as coisas de certa altura", é a outra condição para o cronista relativizar, inclusive, os valores da nova racionalidade positivista, um "retalho de ciência, [...] uma luz melindrosa, que resiste muita vez ao vendaval de um século, e se apaga ao sopro de um livro". ${ }^{20}$ A pena do cronista "não tem cargos d'alma, não evangeliza, não adverte, não endireita os tortos do mundo". Antes o contrário, ela dá atenção ao que já é torto e degradante nos corpos e nos costumes, não por querer convertê-los, mas por rigor analítico.

O que é e o que faz a natureza humana?, pergunta-nos o cronista. O homem é um animal belicoso, consigo e contra os outros, porque a natureza o fez assim. Natureza quer dizer, pascalianamente, tanto a primeira, de ordem instintiva e de origem divina, quanto a segunda, vinculada ao costume e à civilização. Pode até ser que esta tenha destruído aquela outra: "temo muito que essa mesma natureza não venha a ser um primeiro costume, como o costume é uma segunda natureza". ${ }^{21}$ Machado repetirá Pascal, sem acanhamento: "o costume é tudo"22 ou "o costume, leitor amigo, é metade da natureza". ${ }^{23}$ Sendo casual e artificial, o hábito é o princípio que denota as variações humanas, variação geográfica (aquém e além dos Pirineus), variação estética (o nariz de Cleópatra),

\footnotetext{
${ }^{19}$ ASSIS. Obras completas em quatro volumes, p. 388.

${ }^{20}$ ASSIS. Obras completas em quatro volumes, p. 380.

${ }^{21}$ PASCAL. Pensamentos, p. 43 (La 126; Br 93).

${ }^{22}$ ASSIS. Obras completas em quatro volumes, p. 404.

${ }^{23}$ ASSIS. Obras completas em quatro volumes, p. 406
} 
variação histórica (o poder dos reis) e outras mais. Esta segunda natureza é considerada conforme a multiplicidade da experiência, tornando o ser humano "abjeto", "vil" e "em disputa". ${ }^{24}$

Ora, a liberdade com que Pascal utiliza a modalidade alética por exemplo, o argumento da aposta ou quando supõe que a segunda natureza tenha suprimido a primeira - decorre da intenção exortativa dos Pensamentos de persuadir, por meio da razão, aqueles que não foram tocados pela fé, mostrando-lhes a debilidade humana sem Deus. Tratase, é claro, mais de uma exortação que objetiva interferir nas escolhas do leitor do que de uma argumentação que objetive produzir crenças epistemicamente justificadas. A intenção do cronista, por outro lado, não tem nada de apologética, embora o seu vocabulário seja tipicamente pascaliano. Ele não tem cargos d'alma para evangelizar as causas da degradação moral e, ao mesmo tempo, mantem alguma expectativa em relação à porção virtuosa e espiritual do homem:

Talvez o leitor lastime não ver em toda essa enfiada de recreios públicos alguma coisa que entenda com a mentalidade humana. [...] Danças, vistas, tramoias, tudo o que pode nutrir a porção sensual do homem, nada que lhe fale a essa outra porção mais pura; nenhum ou raro desses produtos do engenho, frutos da arte que deu à humanidade o mais profundo dos seus indivíduos. [...] Pobre espírito! Quem pensa em ti, nessa dança macabra de coisas sólidas? Quem oferece alguma coisa ao paladar dos delicados, não corrompido pelo angu do vulgo? Ninguém; tu és, não digo o réprobo, - seria supor que existes, pobre espírito! - tu és como que uma velha figura de retórica, um velho par de sapatos... Talvez lastimes isso, leitor, mas tens o meio de o lastimar, sem nada perder ou pouco. Recolhe-te, de quando em quando, fecha a tua porta, abre a tua despensa intelectual, e saboreia sozinho o manjar dos deuses. Agora, sobretudo, nestas noites de chuva ou de frio, é uma deliciosa volúpia. ${ }^{25}$

Pode ser que "o mais profundo dos seus indivíduos" fosse Pascal, pois a dualidade antropológica está aí descrita em metáforas: o espírito e a sensação, o delicado e o vulgo, a reflexão e a volúpia. Cada termo

${ }^{24}$ PASCAL. Pensamentos, p. 43 (La 127; Br 415).

${ }^{25}$ ASSIS. Obras completas em quatro volumes, p. 435. 
não existe sem o seu contrário - o "réprobo" é característica do "anjo". E mesmo a reflexão sobre as contrariedades é "deliciosa volúpia". O "perpétuo bailado dos espíritos" no Brasil, analisara Machado em crônica anterior, matiza "a uniformidade da vida", ${ }^{26}$ isto é, os processos de simplificação estética e de consumo de produtos culturais massificam a sensibilidade e o intelecto, o gosto e as opiniões.

O espetáculo com animais - por exemplo, as touradas e as corridas com cavalos - divertia a população, alienando-a das questões graves da política, da arte e de si mesma. O alheamento humano é fartamente documentado nessa série de crônicas. Espectadores e "artistas" digladiavam no palco junto aos animais, correndo, saltando e contendo chifres pelas mãos. Ao prazer em assistir touros batalhando pela vida conformava-se "a brandura dos nossos costumes e a graça das nossas maneiras". ${ }^{27}$ Ao ver o costume crescer, o cronista pode analisa-lo filosoficamente: ele nunca participou de touradas, e até as reprova, mas um amigo de fino espírito, ${ }^{28}$ as adora e frequenta:

[S]empre me há de lembrar Santo Agostinho. Conta o grande bispo que o seu amigo Alípio, seduzido a voltar ao anfiteatro, ali foi de olhos fechados, resoluto a não os abrir; mas o clamor das turbas e a curiosidade os abriram de novo e de uma vez, tão certo é que esses espetáculos de sangue alguma coisa têm que fascinam e arrastam o homem [...]. No tempo em que uma vã teoria regulava as coisas do espírito, estes nomes de artista e de arte tinham restrito emprego: exprimiam certa aplicação de certas

\footnotetext{
${ }^{26}$ ASSIS. Obras completas em quatro volumes, p. 417.

${ }^{27}$ ASSIS. Obras completas em quatro volumes, p. 386.

${ }^{28}$ Uma história semelhante é narrada pelo cronista da série "História de quinze dias", em 15 mar. 1877: "Conversava eu há dias com um amigo, grande amador de touradas, e homem de espírito, s'il en fut. [...]. No fundo de cada amador de tourada inocente, há um amador de tourada espanhola. Começa-se por gostar de ver irritar o touro, e acaba-se gostando de o ver matar" (ASSIS. Obras completas em quatro volumes, $\mathrm{p}$. 324). A expressão francesa marca o juízo suspensivo e hipotético do cronista em relação à existência de homens de espírito puros, do mesmo modo que Pascal a utiliza, por exemplo, em "Le nez de Cléopâtre s'il eût été plus court [...]". A história de Alípio ilustra, ainda, uma passagem de Quincas Borba em que o Rubião hesita em assistir ao enforcamento de "dois pretos".
} 
faculdades. Mas as línguas e os costumes modificam-se com as instituições. ${ }^{29}$

Machado repete o juízo negativo de Agostinho sobre o caso. O que interessa é "alguma coisa" que fascina e arrasta o homem e transforma o seu comportamento, por mais horripilante, em costume aceitável. Alípio fora curado de sua paixão por jogos fúteis após a intervenção de Agostinho, que lhe convencera de que este costume viciava. ${ }^{30}$ Apenas chegou a Roma, Alípio sofreu atração irresistível por espetáculos com gladiadores, lançando para si uma solução de compromisso entre a sua virtude e a sua vontade: prometeu triunfar intelectualmente sobre o espetáculo mantendo os olhos fechados. Recorda Agostinho:

Apenas lá chegaram, ocuparam os lugares que puderam. Tudo fervia nas paixões mais selvagens. Alípio, fechando a porta dos olhos, proibiu que sua alma se envolvesse em tal crueldade. E oxalá também tivesse tapado os ouvidos! Porque, em um lance da luta, foi tão grande o clamor da multidão que, vencido pela curiosidade, e julgandose preparado para desprezar e vencer a cena, fosse o que fosse, abriu os olhos. Foi logo ferido na alma mais profundamente do que a ferida física do gladiador a quem desejou contemplar e caiu. Sua queda foi mais miserável que a do gladiador, causa de tantos gritos. Estes, entrandolhe pelos ouvidos, abriram-lhe os olhos, para ferir e abater sua alma, mais temerária do que forte, e tanto mais fraca por apoiar-se em si mesma, em lugar de se apoiar em ti. Logo que viu sangue, bebeu junto a crueldade, e não se afastou do espetáculo; pelo contrário, prestou mais atenção. Assim, sem o saber, absorvia o furor popular e se deleitava naquela luta criminosa, inebriado de sangrento prazer. $^{31}$

A contradição entre a repugnância do espetáculo e a fineza de espírito é comum aos amigos de Agostinho e do cronista de Machado. Contudo, a hipótese deste para explicar e justificar o estado de coisas não é a mesma. Para pensadores como Agostinho e Pascal, a causa da miséria

\footnotetext{
${ }^{29}$ ASSIS. Obras completas em quatro volumes, p. 386-387.

${ }^{30}$ AGOSTINHO. Confissões, p. 126 (VI, 7).

${ }^{31}$ AGOSTINHO. Confissões, p. 128 (VI, 8).
} 
de Alípio ajusta-se à antropologia cristã, segundo a qual a salvação está além da vontade do indivíduo. O próprio Agostinho foi quem primeiro explicitou essa contrariedade fundamental:

[o] homem é intermédio entre o anjo e o bruto: como o bruto e um ser vivo irracional e mortal e como o anjo é racional e imortal - o homem encontra-se no meio, inferior aos anjos e superior aos brutos [pecoribus], pois tem, como os brutos, a mortalidade e, com o os anjos, a razão; é um ser vivente, racional e mortal. ${ }^{32}$

Sendo o homem necessariamente infeliz, por causa de sua mortalidade, apenas a misericórdia divina poderia auxiliá-lo. Eles combatiam toda forma de pelagianismo. Para Machado, a causa da miséria, entendida como hipótese verossímil ou como o antecedente do argumento, é variada: a miséria pode ser resultado da "meninice social" ou da "infância constitucional" brasileira, como quer a interpretação histórico-sociológica de John Gledson, ${ }^{33}$ o que significa que as insuperadas contradições sociais produziam sujeitos abalroados. Neste caso, o cronista deveria estudar "os elementos da luta cotidiana", que pode ser generalizada recolhendo-se exemplos locais: não existe diferença entre os partidos opostos (crônicas 10, I e 12, II). Contudo, Machado não descarta a dedução. A política, por exemplo, também é obra científica, "[em] que os fenômenos sociais sejam sujeitos a regras certas e complexas" ${ }^{34}$ Por isso, a miséria também pode ser consequência de um não sei o quê metafísico que borbulha no sangue humano e que pode ser descrito de maneira ficcional. Cada descrição fantástica confirmará a regra geral. O escrutínio de Paquetá, por exemplo, em que conservadores e liberais alternavam os seus votos a despeito de suas respectivas ideologias, e depois invertiam o resultado, gerando protestos de ambos os lados, cada qual declarando a vitória do outro. Sem acordo, o mesário anulou o trabalho e propôs votarem em candidatos que não residissem em Paquetá, vencendo personagens como Barba-Roxa, João Sem Terra e Nostradamus (crônica 11, I). Essa narrativa fantástica tinha o objetivo de repreender o subdelegado que agira em interesse

\footnotetext{
${ }^{32}$ AGOSTINHO. A cidade de Deus, p. 851-852 (IX, 13).

${ }^{33}$ GLEDSON; GRANJA. Introdução [Notas Semanais], p. 61.

${ }^{34}$ ASSIS. Obras completas em quatro volumes, p. 415.
} 
próprio mandando retirar a força policial que ordenaria a eleição. Essa é apenas a conclusão de uma dedução cujas premissas são condicionais, inverossímeis ou fantásticas.

Neste baile entre o universal e o particular, o cronista instaura uma antropologia tipicamente pascaliana para reinterpretar os acontecimentos semanais, com um acréscimo de ficcionalidade. Para Pascal, era necessário que a religião verdadeira explicasse as "espantosas contraditoriedades". O cronista sugere que essa é apenas uma explicação possível. $\mathrm{O}$ argumento condicional pode se referir tanto ao local quanto ao universal. As perspectivas se alternam, a depender do olhar do intérprete. Esta inovação formal em relação à apologia exortativa de Pascal permite ao narrador, inclusive, discordar, emendar e redescrever a metáfora compreensiva do anjo e da besta:

\begin{abstract}
Pascal dizia que o homem não era anjo nem besta. Eu peço licença às suas ilustres cinzas para dizer que é uma e outra coisa. E esta natureza semiangélica e semibestial é que faz justamente a nossa grandeza, porque em suma podíamos ser exclusivamente bestas (e o somos às vezes) ${ }^{35}$
\end{abstract}

\title{
Considerações finais
}

As crônicas de 1878 conformam a perspectiva narrativa de um ironista com interesses metafísicos. O que faz o cronista é redescrever a metáfora antropológica pascaliana a respeito do anjo e da besta. Esta antropologia assinala a possibilidade de existirem verdades inacessíveis ao ser bestializado. Segue-se a necessidade da aposta e a verossimilhança da doutrina cristã. A adesão do cronista em relação à dramatização dos aspectos bestializantes do ser humano não o leva à adoção da perspectiva cristã. Pelo contrário, pretendeu-se mostrar que a perspectiva ironista e metafísica se opõe ao discurso bíblico e ao receituário cristão. A aposta

\footnotetext{
${ }^{35}$ ASSIS [Dr. Semana]. Badaladas. p. 4298. Os bibliógrafos machadianos têm dúvidas sobre a atribuição de autoria da série de crônicas "Badaladas". Machado era um dos cronistas que escreviam sobre o pseudônimo Dr. Semana. Por isso, os editores das Obras completas em quatro volumes foram cautelosos ao não recolher esses textos. $\mathrm{Na}$ obra machadiana encontramos a mesma discordância em crônica da Revista Brasileira (ASSIS. Obras completas, p. 1211) e nas Memórias póstumas de Brás Cubas (ASSIS. Obras completas, p. 693).
} 
não é necessária porque o próprio argumento pela doutrina compõe-se de artifícios retóricos que beiram à condicionalidade, recorrem ao absurdo e ao contrafactual, tais como as peças de ficção. Neste sentido, o estilo da crônica se adapta à volubilidade e à deformidade natural dos personagens, preenchendo as lacunas e os defeitos com ditos da imaginação, joguetes espirituosos e hipóteses verossímeis. Como tudo indica, essa volubilidade essencial é o que permite a consideração filosófica da obra de Machado de Assis, a despeito, quer dizer, ainda mais quando ela é expressa num aparato ficcional. Neste caso, a intenção teórica do próprio Machado de tornar-se artista e não filósofo, é subtraída pela recepção e pelo impacto da obra sobre nós, humanos.

\section{Referências}

AgOSTINHO. A cidade de Deus. Tradução de J. Dias Pereira. 2. ed. Lisboa: Fundação Calouste Gulbenkian, 2000. v. 2.

AGOSTINHO. Confissões. Tradução de J. Oliveira Santos e A. Ambrósio de Pina. 2. ed. São Paulo: Abril Cultural, 1980.

ASSIS, Joaquim Maria Machado de [Dr. Semana]. Badaladas. Semana Ilustrada, Rio de Janeiro, n. 538, 2 abr. 1871, f. 4298. Disponível em: http://memoria.bn.br/DocReader/702951/4315. Acesso em 30 abr. 2019.

ASSIS, Joaquim Maria Machado de. Obra completa em quatro volumes. Organização de Aluizio Leite, Ana Lima Cecílio, Heloisa Hahn. São Paulo: Nova Aguilar, 2015. v. 4.

BOSI, Alfredo. O enigma do olhar. São Paulo: Ática, 2000.

COUSIN, Victor. Des Pensées de Pascal: rapport à l'Académie française sur la nécessité d'une nouvelle édition de cet ouvrage. Paris: Librairie Philosophique de Ladrange, 1843. Disponível em: http:/gallica.bnf.fr/ ark:/12148/bpt6k37212t. Acesso em: 19 abr. 2019.

DIXON, Paul. A auto-referência e o paradoxo em Dom Casmurro. Brasil/ Brazil, Porto Alegre, v. 1, p. 30-40, 1988.

DIXON, Paul. Teoria da mente, Machado de Assis, e a escola realista. Machado de Assis em Linha, São Paulo, v. 2, p. 84-93, 2008.

GLEDSON, John; GRANJA, Lúcia. Introdução. In: (org.). Notas Semanais. Campinas: Editora da Unicamp, 2008. 
GRANJA, Lúcia. Machado de Assis, esse escritor monstruoso (entre aberrações e espetáculos). Olho d'água, São José do Rio Preto, n. 9, v 1, p. 142-152, jan.-jun. 2017.

MAIA NETO, J. R. Machado de Assis: skepticism and literature. Latin American Literary Review, [S.l.], v. 18, n. 36, p. 26-35, 1990.

MARGUTTI PINTO, Paulo. Richard Rorty and Machado de Assis: Two Different Ways of Coping with Ironism. Cognitio, São Paulo, v. 8, n. 1, p. 115-139, jan.-jun. 2007.

MASSA, Jean-Michel. A juventude de Machado de Assis. Rio de Janeiro: Civilização Brasileira, 1971.

MATHIEU, Francis. Mme de Lafayette et la condition humaine: Lecture pascalienne de La Princesse de Clèves. Cahiers du Dix-Septième: An Interdisciplinary Journal, Athens, GA, n. XII, v. 1, p. 61-85, 2008.

PASCAL, Blaise. Pensamentos. Tradução de Mário Laranjeira. 2. ed. São Paulo: Martins Fontes, 2005.

PRATT, Mary Louise. Toward a Speech Act Theory of Literary Discourse. Bloomington: Indiana University Press, 1977.

Recebido em: 30 de abril de 2019. Aprovado em: 25 de setembro de 2019. 